\title{
Activities and agreements of the Hungarian- Czechoslovakian Boundary Commission (1947-1949)
}

\author{
Dr. Gábor HOLLÓSI, PhD.
}

\begin{abstract}
By the time Czechoslovakia occupied Dunacsún (Čunovo), Horvátjárfalu (Jarovce) and Oroszvár (Rusovce) on 15 October 1947 - the three villages that Hungary had to cede in accordance with the Paris Peace Treaty - negotiations between the two parties of the Hungarian-Czechoslovakian Boundary Commission had barely begun. The Peace Treaty called for a boundary commission composed of the representatives of the two governments to determine the exact boundaries of the new frontier within two months. Because the commission also had to make decisions on other related questions, talks lasted until the beginning of 1949. Making use of documents housed in the National Archives of Hungary, we present the structure, activities and agreements of the Hungarian-Czechoslovakian Boundary Commission in the work below.
\end{abstract}

\section{Keywords}

Hungarian-Czechoslovakian Boundary Commission, Paris Peace Treaty, territorial ceding, Čunovo, Jarovce, Rusovce

\section{Introduction}

\section{Historical background}

Relations between Hungary and Czechoslovakia reached a historic low point in the postWWII period. Although the First Vienna Award ${ }^{1}$, which returned the southern part of Slovakia to Hungary, had corresponded to ethnic borders, Hungarian troops and administration were forced to retreat to the pre-1938 borders in accordance with the ceasefire agreement signed in Moscow on 20 January 1945. In order to hold onto the evacuated areas, it was in the interests of Czechoslovakia to remove the borderland minorities by the time the peace treaty was concluded.

The Košice government program of April 1945, which was "legitimized" by the Beneš decrees, accused the ethnic German and Hungarian residents of wrecking the Czechoslovak Republic and allowed for their expulsion. The deportation of the German and Hungarian populations and the show trials in the people's tribunals were begun. However, in contrast to the Soviet Union, the Western powers did not accept the unilateral expulsion of the Hungarians; a population exchange agreement was thus concluded on 27 February 1946. This did not lead to the results desired by Czechoslovakia. Thus, in the end, a re-

1 First Vienna Award was held at 2 November 1938. 
Slovakization was attempted: anyone who declared himself as Slovak could regain his Czechoslovakian citizenship. ${ }^{2}$

The proposal, which had already existed in Czechoslovak military circles between the two wars, that the Petržalka bridgehead should be widened such that the state borders would be at least twenty-five kilometers away from Bratislava instead of the previous six (thus placing the city outside the range of artillery cannons) was formally formulated in November 1945. Therefore, Czechoslovakia demanded five Hungarian townships at the Paris Peace Conference, arguing that urban development of Bratislava was possible only in their direction. Nevertheless, mainly due to American pressure, ${ }^{3}$ Czechoslovakia received only three of the five: Dunacsún, Horvátjárfalu and Oroszvár, which were later renamed Čunovo, Jarovce and Rusovce, respectively. Oroszvár was mainly ethnic German (73 \%), while Horvátjárfalu and Dunacsún were majority Croatian settlements (53.9\% and $47.8 \%$, respectively, and in the case of the latter, only a relative plurality). ${ }^{4}$

\section{The Hungarian-Czechoslovakian Boundary Commission}

By the time Czechoslovakia occupied Dunacsún, Horvátjárfalu and Oroszvár on 15 October 1947 - the three villages that Hungary had to cede in accordance with the Paris Peace Treaty - negotiations between the two parties of the Hungarian-Czechoslovakian Boundary Commission had barely begun. ${ }^{5}$ The Peace Treaty called for a boundary commission composed of the representatives of the two governments to determine the exact boundaries of the new frontier within two months. ${ }^{6}$ Because the commission also had to make decisions on other related questions, talks lasted until the beginning of 1949. Making use of documents housed in the National Archives of Hungary, ${ }^{7}$ we present the structure, activities and agreements of the Hungarian-Czechoslovakian Boundary Commission in the work below.

2 See in detail: HORVÁTH, Attila: A Beneš-dekrétumok és a hozzá kapcsolódó magyarellenes intézkedések (1945-1949) [The Beneš decrees and the anti-Hungarian measures connected to them (1945-1949)], in: Kisebbségvédelem. A Kisebbségi Jogvédő Intézet Tudományos Folyóirata [Protection of Minorities. The Academic Journal of the Institute for the Protection of Minority Rights (IPMR)], 1, 2019, 1, 144-158. (Available in Hungarian).

3 See in detail: ROMSICS, Ignác: Az 1947-es párizsi békeszerződés [The 1947 Paris Peace Treaty], Budapest 2006, 206, 212-223. (Available in Hungarian).

4 HOLLÓSI, Gábor: Az "emberi és polgári jogok" értelmezése pozsonyi hídfő kiszélesítése kapcsán [The meaning of "human and civic rights" in connection with the enlargement of the Bratislava bridgehead], in: lustum Aequum Salutare, 12, 2016, 3, 143. (Available in Hungarian).

5 Please see: HOLLÓSI, Gábor: A pozsonyi hídfő. A Magyar-Csehszlovák Határrendező Bizottság tárgyalásai (1947-1949) [The Bratislava Bridgehead: The Negotiations of the Hungarian-Czechoslovakian Boundary Commission (1947-1949)], Budapest 2017. (Available in Hungarian).

6 "The exact line of the new frontier between Hungary and Czechoslovakia laid down in the preceding subparagraph shall be determined on the spot by a boundary Commission composed of the representatives of the two Governments concerned. The Commission shall complete its work within two months from the coming into force of the present Treaty." Treaty of Peace with Hungary - 10 February 1947. Article I., 4. (d). Law Library of Congress, online: https://www.loc.gov/law/help/us-treaties/bevans/m-ust000004-0453.pdf.

7 National Archives of Hungary (hereinafter referred only as NAH), fund "A Külügyminisztérium "adminisztratív« iratai, 1945-1994" ("Administrative" Documents of the Hungarian Ministry of Foreign Affairs, 1945-1994; hereinafter referred to only as XIX-J-1-k), carton 69, file "A Magyar-Csehszlovák Határrendező Bizottság jegyzökönyvei 1947. október 11. és december 16. között" (The minutes of the Hungarian-Czechoslovakian Boundary Commission between 11 October and 16 December 1947; available in Hungarian). 


\section{The composition and structure of the Hungarian government delegation}

The Hungarian government delegation of the Hungarian-Czechoslovakian Boundary Commission was established by the decision of the Council of Ministers on 19 September 1947. The President of the Republic himself appointed the members of the delegation. Originally Béla Bojta, ${ }^{8}$ State Secretary of the Office of the Prime Minister, was considered for the role of chairman. Bojta's appointment seemed so likely that he even staffed the delegation. In the end, however, Roland Kiss, ${ }^{9}$ State Secretary of Domestic Affairs, who had been initially eyed for the position of Permanent Deputy to the President, was appointed as chairman instead. ${ }^{10}$ The members of the delegation were Envoy Extraordinary and Delegated Minister Viktor Szondy ${ }^{11}$; József Bartha, on behalf of the Ministry of Transport; Andor Zalányi, ${ }^{12}$ on behalf of the Ministry of Agriculture; and Sándor Karcsay, ${ }^{13}$ on behalf of the Ministry of Internal Affairs, who was also the secretary of the delegation. ${ }^{14}$

The work of the chairman and the members was supported by experts. Additionally, János Bogárdi, ${ }^{15}$ Director of the Institute for Hydrography, as a water management expert; László Hollós, on behalf of the Ministry of Finance, as a financial and economics expert; István Hazay, ${ }^{16}$ Head of the Department for Survey at the Ministry of Finance, as an expert on the matters of marking out borders; Tibor Mikó, ${ }^{17}$ on behalf of the Prime Ministry, as an expert

8 Lawyer Ernő Béla Bojta (born Burger) (1899-1969) organized the National Council of People's Tribunals after WWII.

9 Roland Kiss (1888-1967) referred to himself as the "Bible-carrying socialist". His father had been a saddler. Kiss joined the Hungarian Social Democratic Party in 1917, two years before the proclamation of the Republic of Councils in Hungary (Hungarian Soviet Republic). He took part in the management of various Protestant organizations during the Interwar Period. He was a member of the committee which oversaw the separation of the state and church in 1948. He accepted the secular chairmanship of the General Convention of the Reformed Church through the Hungarian Workers' Party (the party of the state) in 1949.

10 NAH, XIX-J-1-k, carton 71, doc. "Pesti elökészitő iratok" (Pest Preparatory Papers; available in Hungarian).

11 Viktor Szondy (1891-?) was an international legal expert and a professor at Budapest University. He took over the Department of Private International Law at the Ministry of Foreign Affairs in 1937. He also led simultaneously the Department of International Administrative Law from 1941. After WWII, he worked as the head of the Department for Prisoners of War.

12 Andor Zalányi, a university private professor, was habilitated at the Agricultural University in 1947. He was the chairman of the Hungarian delegation of the Economic Sub-commission of the Hungarian-Czechoslovakian Mixed Commission for population exchange. In April 1949, he was sentenced (in a show trial) to a two-year prison term in "the case of the conspiracy of the representatives of the Ministry of Agriculture".

13 Sándor Karcsay (1915-1999) was a legal expert. Having been compulsory retired, he initially found new work as an insurance agent, after which he joined the National Translating Office. He was the Deputy Chairman of the international Christian Democratic Union after the System Changeover in Hungary in 1989/90.

$14 \mathrm{NAH}, \mathrm{XIX}-\mathrm{J}-1-\mathrm{k}$, carton 69, doc. "Jegyzökönyv amely felvétetett a magyar-csehszlovák határrendező bizottság 1947. október 11-én délelött 10-órakor tartott üléséról" (Minutes Drawn Up during the Session of the Hungarian-Czechoslovakian Boundary Commission at 10:00 a. m. on 11 October 1947; available in Hungarian).

15 János Bogárdi (born Bogner) (1909-1998) was a hydraulic engineer, hydrologist and professor.

16 István Hazay (1901-1995) was a surveyor, professor and full member of the Hungarian Academy of Sciences.

17 Tibor Mikó was one of three men who took part not only in the work of the Boundary Commission but was also present at the Paris Peace Conference (1946). Before moving to Munich, he emigrated to Vienna in 1948. He later worked at Radio Free Europe. 
on nationalities and as a liaison; Imre Jakabffy, ${ }^{18}$ Head of Department at the Institute for Political Sciences, as a statistician and cartographer; and Lieutenant-Colonel / Chief of Staff Jenő Czebe ${ }^{19}$ all participated in the work of the delegation. We should also mention the administrative secretary of the delegation: Mrs. Józsefné Raáb, who was sent from the Prime Ministry to Bratislava.

An interdepartmental demarcationary commission supported the Hungarian government delegation as a "background institute". Three sub-commissions were formed within this structure, which included staff not listed above. Roland Kiss was also the chairman of the Sub-commission for Demarcation. The Sub-commission for Matters Related to the Non-Relocated Population was directed by Viktor Szondy. The chairmanship of the Subcommission for Economic, Property and Transportation Matters Related to the Ceded Territory was shared between József Bartha and Andor Zalányi. Sándor Karcsay took part in the sessions of all three sub-commissions as a liaison. His mission was "to keep all subcommittee discussed matters in line with respect to internal affairs". ${ }^{20}$

\section{First term}

The government delegations of the Hungarian-Czechoslovakian Boundary Commission met in Bratislava on 11 October 1947. ${ }^{21}$ During the short two-month period (as outlined by the Peace Treaty), they were able to agree only on the most pressing issues.

One of the problems that needed to be addressed was that a section of highway tying Budapest and Vienna together had ended up in Czechoslovakia as a result of the territorial switch. Thus direct traffic flow between the two capitals was interrupted. Scheduled and unscheduled transportation of people and goods was worked out by the so-called "passage agreement", 22 although under its terms, the escort provided by Czechoslovakian toll authorities was not free. The agreement was extended indefinitely until the direct highway connection could be restored between Hungary and Austria. It is important to note that unlike the below mentioned agreements, the "passage agreement" came into force as a

18 Imre Jakabffy (1915-?) was a legal expert, statistician for nationalities and cartographer. He was the rapporteur for Romania at the Institute for Political Sciences (Pál Teleki Scientific Institute) during WWII. He attended the Paris Peace Conference as an expert of the Hungarian delegation. His ironically written memoir on the first term of the Hungarian-Czechoslovakian Boundary Commission was published in 1998. Please see: JAKABFFY, Imre: A pozsonyi hídfő [The Bratislava Bridgehead], in: Életünk [Our Life], 36, 1998, 10, 891-919. (Available in Hungarian). 19 Jenő Czebe (1914-1949) was the expert on prisoners of war for the military group of the Hungarian delegation at the Paris Peace Conference. He was arrested on a trumped-up charge of high treason. He tried to escape during his interrogation but was shot and killed.

$20 \mathrm{NAH}, \mathrm{XIX}-\mathrm{J}-1-\mathrm{k}$, carton 71, file "Pesti előkészítő iratok" (Pest Preparatory Papers), doc. "Jelentés Miniszter Úrnak a határrendezó bizottság tagjairól" (Report to the Minister on the Members of the Boundary Commission. Budapest, 3 October 1947; available in Hungarian).

$21 \mathrm{NAH}$, XIX-J-1-k, carton 69, doc. "Jegyzőkönyv amely felvétetett a magyar-csehszlovák határrendező bizottság 1947. október 11-én délelött 10-órakor tartott üléséröl" (Minutes Drawn Up during the Session of the Hungarian-Czechoslovakian Boundary Commission at 10:00 a. m. on 11 October 1947; available in Hungarian).

$22 \mathrm{NAH}$, fund "A Külügyminisztérium lejárt szerződései" (Expired treaties of the Hungarian Ministry of Foreign Affairs; hereinafter referred to only as XIX-J-1-f), carton 59, doc. "Egyezmény a Budapest-wieni közút csehszlovák szakaszán átmenő forgalom szabályozása tárgyában. - Dohoda o úprave pasážnej dopravy na československom úseku verejnej cesty Budapest-Wien" (Agreement Concerning the Regulation of the Transit Traffic on the Czechoslovakian Section of the Budapest-Vienna Highway; available in Hungarian). 
separate entity. It had validity prior to the issuing of the Final Protocol of the HungarianCzechoslovakian Boundary Commission (on 22 December 1947). ${ }^{23}$

Through extremely difficult negotiations, the Hungarian delegation managed to bring into force that provision of the Peace Treaty through which " (...) the dam and spillway within the village limits of Rajka will remain on Hungarian territory" 24 . The reason why was the incorrectly indicated borderline in the map annex of the Peace Treaty. Moreover, data in the text related to distance were also broadly inexact. The significance of this question was that after the ceding of the Dunacsún Spillway, flood prevention of the settlements located on the Hungarian Szigetköz, which included the city of Györ, was provided by that very same spillway ('Szigetköz' is an island between the Great Danube and the Moson-Danube). Since the Hungarian government delegation had not accepted the population exchange in this area, the Czechoslovakian delegation made a statement related to the matter of the people of the territory that Hungary had to cede to Czechoslovakia. Another statement was also made concerning private law and administrative issues. The first statement guaranteed Czechoslovakian citizenship and non-discrimination of the non-relocated population; the second one included recognition of Hungarian civil service periods and the granting of social security benefits (e.g. pensions). Czechoslovakia, however, did not observe the rules in these statements.

The parties could not agree on financial issues thus, the clause "final settlement of those will be a matter of interstate negotiations" was included only in the Final Protocol. It was also stated that the parties would conclude a water agreement with each other in three months after the finalization of the border.

\section{Second term}

The water agreement had already been prepared by the time the second term began. A Hungarian-Czechoslovakian mixed sub-commission was created for this purpose. (Mixed sub-commissions prepared the agreements in other cases also, but simultaneously as the plenary sessions were underway, in contrast to the water issues). The talks of the Water

$23 \mathrm{NAH}, \mathrm{XIX}-\mathrm{J}-1-\mathrm{k}$, carton 70, doc. "Zárójegyzőkönyv a párisi békeszerződés 1. cikke 4. pontjának »d« alpontja értelmében a magyar és a csehszlovák kormány képviselőiból alakított Határrendező Bizottság munkálatairól" (Final Protocol on the Work of the Boundary Commission Composed of the Representatives of the Hungarian and the Czechoslovakian Governments through Article I., 4. /d/ of the Paris Peace Treaty; available in Hungarian).

24 "Hungary shall cede to Czechoslovakia the villages of Horvathjarfalu, Oroszvar and Dunacsun, together with their cadastral territory as indicated on Map No. IA3 annexed to the present Treaty. Accordingly, the Czechoslovak frontier on this sector shall be fixed as follows: from the point common to the frontiers of Austria, Hungary and Czechoslovakia, as they existed on 1 January 1938, the present Hungarian-Austrian frontier shall become the frontier between Austria and Czechoslovakia as far as a point roughly 500 meters south of hill 134 (3.5 kilometers northwest of the church of Rajka), this point now becoming common to the frontiers of the three named States; thence the new frontier between Czechoslovakia and Hungary shall go eastwards along the northern cadastral boundary of the village of Rajka to the right bank of the Danube at a point approximately 2 kilometers north of hill 128 (3.5 kilometers east of the church of Rajka), where the new frontier will, in the principal channel of navigation of the Danube, join the Czechoslovak-Hungarian frontier as it existed on 1 January 1938; the dam and spillway within the village limits of Rajka will remain on Hungarian territory." - Treaty of Peace with Hungary - 10 February 1947. Article I., 4. (c). Law Library of Congress, online: https://www.loc.gov/law/help/us-treaties/ bevans/m-ust000004-0453.pdf. 
Sub-commission began in Bratislava on 9 January 1948. ${ }^{25}$ However, the tasks of the second term of the Boundary Commission encompassed more than simply negotiating the water agreement and determining the location of the new frontier. New questions arose related to the grievances of the Hungarians in Czechoslovakia, especially the individuals who had "voluntarily" left the ceded territory.

Roland Kiss still headed the Hungarian delegation of the Boundary Commission during the second term, which took place from 5 May to 2 July 1948. "Due to prior commitments", Ivan Horvath $^{26}$ (Envoy Extraordinary and Delegated Minister, Vice-Chairman of the Slovakian National Council), leader of the Czechoslovakian delegation, was replaced by Ján Bujna (Embassy Councilor, Chargé d'Affaires of the Republic of Czechoslovakia in Budapest) on 22 June. ${ }^{27}$ Some new names were added to the list of experts who helped the work of the Hungarian delegation: Nándor Hegedüs and Jenő Monár ${ }^{28}$ (from the Prime Ministry), and Oszkár Petényii ${ }^{29}$ (from the Ministry of Agriculture).

The talks were very tense. Unidentified persons ripped the Hungarian flag off Roland Kiss' car in Bratislava on the night of 26 June. ${ }^{30}$ The Hungarians in Czechoslovakia also inundated the commission with complaints against the authorities. The minutes of the session of 1 July recorded one of the more flagrant incidents. "[Roland Kiss] must state that the Hungarian population of the three villages is being persecuted. (...) He felt obligated to share his exasperation [at the following case]. He mentions that a woman employed by the Office of the Hungarian Delegation met him today. Through tears, she informed him

$25 \mathrm{NAH}, \mathrm{XIX}-\mathrm{J}-1-\mathrm{k}$, carton 71, file "Víz" (Water), doc. "Jegyzőkönyv a magyar-csehszlovák Határrendezó Bizottság Vízügyi Albizottságának Bratislavában, 1948. évi január hó 9-től január hó 15-ig tartott tárgyalásairól" (Protocol on the Negotiations of the Water Sub-Commission of the Hungarian-Czechoslovakian Boundary Commission in Bratislava from 9 to 15 January 1948; available in Hungarian).

26 Ivan Horváth (1904-1960) was Czechoslovakian ambassador to Hungary. He was sentenced to twenty-two years in prison in a show trial of "Slovakian bourgeois nationalists" in Bratislava in 1954.

$27 \mathrm{NAH}, \mathrm{XIX}-\mathrm{J}-1-\mathrm{k}$, carton 71, doc. "Kormánybizottsági jelentés a Magyar-Csehszlovák Határrendező Bizottság 1948. évi második ülésszakáról" (Government Commission Report on the Second Term of the HungarianCzechoslovakian Boundary Commission, 15 August 1948; available in Hungarian). - See also: NAH, fund "A Külügyminisztérium »titkos« iratai, 1945-1995" "Secret" Documents of the Hungarian Ministry of Foreign Affairs, 1945-1995; hereinafter referred to only as XIX-J-1-j), carton 48, file "Magyar-Csehszlovák Határrendező Bizottság" (Hungarian-Czechoslovakian Boundary Commission), doc. "Jegyzökönyv mely felvétetett a Határrendezö Bizottság 1948. évi június hó 22.-én megtartott üléséröl" (Minutes Drawn Up during the Session of the Boundary Commission on 22 June 1948; available in Hungarian). - In the period sources, we did not find any reference to the real reason for Horvath's departure.

28 Monár's role was monitoring nationality policy changes regarding the Czechoslovakian-Hungarian population exchange at the Prime Ministry after the war.

29 Oszkár Petényi was a senior engineer and former head of the Fluvial Engineering Office in Győr.

$30 \mathrm{NAH}, \mathrm{XIX}-\mathrm{J}-1-\mathrm{j}$, carton 48, doc. "Jegyzókönyv mely felvétetett a Határrendező Bizottság 1948. évi június hó 26-án Bratislavában tartott üléséröl" (Minutes Drawn Up during the Session of the Boundary Commission in Bratislava on 26 June 1948). Melléklet (Annex, available in Hungarian). - See also: NAH, XIX-J-1-k, carton 48, file "Vegyes" (Miscellaneous), doc. "Zászló-gyalázás" (Desecrated Flag, 12 May 1948; available in Hungarian). 
that Károly Egyházi, her father and 'white card' resident of Dunajská Streda, had been evicted from his own home and placed in the adjacent yard while lying on his deathbed. (...)" $)^{\prime 31}$ In the end, negotiations came to a standstill. There were no substantive results of the second term. ${ }^{32}$

\section{Third term}

After the negotiations halted, there were several months of informal talks in Budapest and Balatonföldvár (a settlement on the southern shore of Lake Balaton). Roland Kiss wrote a letter to the chairman of the Czechoslovakian delegation on 17 July 1948, in which he stated that negotiations would resume on the condition that on-site verification by the chairmen of both delegations of the Boundary Commission that the rules pertaining to the residents of the ceded villages in the Final Protocol were in fact being followed. ${ }^{33}$ Bujna informed Kiss over the phone that he had received his letter, and that he wished to talk to Kiss in person. Kiss invited Bujna to Balatonföldvár, where he was spending his summer holiday. On his 5 August visit, Bujna informed Kiss that he anticipated that the Czechoslovakian government would consent to the on-site verification of the fulfillment of the points added to the Final Protocol. ${ }^{34}$

This was the basis of the third term, which was held in Bratislava between 4 and 14 October 1948. ${ }^{35}$ The water agreement ${ }^{36}$ guaranteeing flood control for the neighboring Hungarian territory and the feeding of the Moson-Danube with streamflow was signed at this time. (Along with Dunacsún, the derivative section of the Moson-Danube and a 9.6 kilometres long part of dam were also ceded by the Paris Peace Treaty). Czechoslovakia promised that

$31 \mathrm{NAH}, \mathrm{XIX}-\mathrm{J}-1-\mathrm{j}$, carton 48, doc. "Jegyzőkönyv mely felvétetett a Határrendező Bizottság 1948. évi július hó 1-én d.u. 6 órakor Bratislavában tartott üléséröl" (Minutes Drawn Up during the Session of the Boundary Commission in Bratislava at 6:00 p. m. on 1 July 1948; available in Hungarian). - Cf.: "All human beings are born free and equal in dignity and rights. They are endowed with reason and conscience and should act towards one another in a spirit of brotherhood." The Universal Declaration of Human Rights, Article 1, online: www.un.org "White card" was the common name of the notice for people who were designated for displacement under the population exchange. It was delivered ex officio by the Office of the Hungarian delegate.

$32 \mathrm{NAH}, \mathrm{XIX}-\mathrm{J}-1-\mathrm{k}$, carton 71, file "Külügybe jelentések" (Reports to the Ministry of Foreign Affairs), doc. "Vázlatos tájékoztató jelentés a Magyar Határrendező Bizottság tárgyalásainak állásáról 1948. július 8-án" (Schematic Information Report on the Progress of the Negotiations of the Hungarian Boundary Commission on 8 July 1948. By Roland Kiss; available in Hungarian).

$33 \mathrm{NAH}, \mathrm{XIX}-\mathrm{J}-1-\mathrm{k}$, carton 71, doc. "Kormánybizottsági jelentés a Magyar-Csehszlovák Határrendező Bizottság 1948. évi második ülésszakáról" (Government Commission Report on the Second Term of the HungarianCzechoslovakian Boundary Commission, 15 August 1948; available in Hungarian).

$34 \mathrm{NAH}, \mathrm{XIX}-\mathrm{J}-1-\mathrm{k}$, carton 71, doc. "Kormánybizottsági elnöki jelentés a Magyar-Csehszlovák Határrendező Bizottság tárgyalásainak újrafelvételéról" (Report of the Chairman of the Government Commission on the Resumption of the Negotiations of the Hungarian-Czechoslovakian Boundary Commission, 23 August 1948; available in Hungarian). Roland Kiss' manuscript: NAH, XIX-J-1-k, carton 73.

$35 \mathrm{NAH}, \mathrm{XIX}-\mathrm{J}-1-\mathrm{k}$, carton 71, doc. "Jelentés a záró ülésszakról" (Report on the Final Term; available in Hungarian).

$36 \mathrm{NAH}, \mathrm{XIX}-\mathrm{J}-1-\mathrm{k}$, carton 71, file "Víz" (Water), doc. "Egyezmény a Magyar Köztársaság és a Csehszlovák Köztársaság között a párisi békeszerződés 1. cikk 4. pontjának "c« bekezdése értelmében foganatosított területátengedéssel kapcsolatban felmerülö egyes vízügyi kérdések tárgyában" (Agreement between the Hungarian Republic and the Czechoslovakian Republic on Individual Water Issues that Arose from the Territorial Ceding Under Paragraph »c« of Point 4 of Article 1 of the Paris Peace Treaty; available in Hungarian). 
it would share the water level data of the floodometer in Rusovce twice daily with Hungary until the new floodometer was built in the Hungarian territory. However, Czechoslovakia was unwilling to pay compensation for the assets (exempli gratia, dams) of the Association for Regulating the Raba (River) on the ceded territory. The Boundary Commission thus postponed this question to the matter of "financial negotiations related to the peace treaty".

Supplementary Protocol No. 1 and 2 were also signed during the third term. ${ }^{37}$ Protocol No. 1 concerned the work related to determining the border, while Protocol No. 2 related to the people who had "voluntarily" left. The people who had "voluntarily" resettled to Hungary could do whatever they wished with their belongings; whoever had already left the ceded territory was allowed to return for any belongings left behind. The Population Exchange Agreement (PEA) of 27 February 1946, and the resolutions passed by the mixed commission created by the PEA were used in principle for inventory and evaluation of immobile property.

\section{Fourth term}

The translation into French was made more difficult because of innumerable differences between the Hungarian and Slovakian texts of Supplementary Protocol No. 1 and the water agreement. Thus a fourth term was convened in Prague in December 1948 and at the beginning of January 1949, during which the two sides reconciled the language discrepancies. ${ }^{38}$ The question of where the borderline would be drawn was still not determined when the work of the Hungarian-Czechoslovakian Boundary Commission concluded. The Czechoslovakian delegation proposed that the Boundary Commission review the entire Trianon border because border landmarks had been removed as a result of the return of the territory to Hungary via the First Vienna Award on 2 November

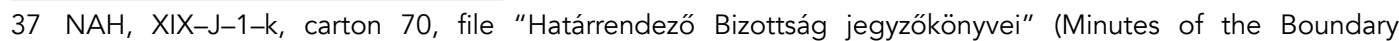
Commission), doc. "I. számú pótjegyzőkönyv a Bratislavában 1947. évi december 22.-én kelt Zárójegyzőkönyvhöz a határkitúzési munkálatok tárgyában" (Supplementary Protocol No. 1 on the Works of Determining the Location of the Border to the Final Protocol in Bratislava dated on 22 December 1947; available in Hungarian). - NAH, XIX-J-1-k, carton 70, file "Határrendező Bizottság jegyzőkönyvei" (Minutes of the Boundary Commission), doc. "II. Pótjegyzőkönyv a párisi békeszerződés 1. cikk 4. pontjának »d« alpontja értelmében a magyar és csehszlovák kormány képviselöiböl alakított Határrendező Bizottság munkálatairól szóló, Bratislavában 1947. évi december hó 22-én kelt Zárójegyzókönyvhöz" (Supplementary Protocol No. 2 to the Final Protocol on the Works of the Boundary Commission, which was Composed of the Representatives of the Hungarian and Czechoslovakian Governments According to the Sub-point »d« of Point 4 of Article 1 of the Paris Peace Treaty, in Bratislava dated on 22 December 1947; available in Hungarian).

38 NAH, XIX-J-1-k, carton 70, doc. No. 22.323, "Kormánybizottsági jelentés az 1948. október 9-én aláírt I. számú Pótjegyzőkönyv francia szövegének megállapítása tárgyában Prágában folytatott tárgyalásokról" (Government Commission Report on the Prague Negotiations Relating to the Determination of the French Text of the Supplementary Protocol No. 1 signed on 9 October 1948; available in Hungarian). - Prague negotiations were between 8 and 15 December 1948, and between 4 and 12 January 1949. - See also: NAH, XIX-J-1-k, carton 70, doc. "Kormánybizottsági jelentés a Magyar Köztársaság és a Csehszlovák Köztársaság között a párisi békeszerződés 1. cikk 4. pont »c" alpontja értelmében foganatosított területátengedéssel kapcsolatos vízügyi kérdések tárgyában Bratislavában 1948. évi október hó 9. napján aláirt egyezmény francia szövegének megállapitása iránt Prágában folytatott tárgyalásokról" (Government Commission Report on the Prague Negotiations relating to the Determination of the French Text of the Agreement between the Hungarian Republic and the Czechoslovakian Republic in Bratislava signed on 9 October 1948, on Water Issues that Arose from the Territorial Ceding Under Sub-point »c" of Point 4 of Article 1 of the Paris Peace Treaty. 1 March 1949; available in Hungarian). 
1938. According to the Council of Ministers of Hungary, however, this task was outside the authority of the Boundary Commission of the Peace Treaty. The Hungarian side thus decided to delegate a new commission. A State Commission for Border Affairs was formed for this purpose. ${ }^{39}$

\section{Conclusion}

In the extremely tense situation following the WWII, the Hungarian government delegation of the Hungarian-Czechoslovakian Boundary Commission fulfilled its sad obligation to carve out once again a small piece of the territory of the country. Although negotiations dragged on considerably, the Hungarian delegation concluded the agreements which it considered necessary. Implementation of the agreements varied in Czechoslovakia. For instance, understanding the importance of the "passage" agreement, the Czechoslovak government was ready to extend it four times. At the same time, implementation of the agreement guaranteeing citizenship and non-discrimination for the non-relocated population stalled. It would be interesting to find out from contemporary Czechoslovak sources what exact instructions the Czechoslovak delegation, initially headed by Ivan Horvath and then Ján Bujna, had received, for negotiations with the Hungarian side. We hope that the relevant conclusions of Czech and Slovak researchers will be published in Hungary sooner rather than later, so that any one-sided perspectives in our work may be reconciled.

\section{References}

National Archives of Hungary (hereinafter referred only as NAH)

$\mathrm{NAH}$, fund "A Külügyminisztérium lejárt szerződései" (Expired treaties of the Hungarian Ministry of Foreign Affairs; hereinafter referred to only as XIX-J-1-f), carton 59, doc. "Egyezménya Budapest-wieni közút csehszlovák szakaszán átmenőforgalom szabályozása tárgyában. - Dohoda o úprave pasážnej dopravy na československom úseku verejnej cesty Budapest-Wien" (Agreement Concerning the Regulation of the Transit Traffic on the Czechoslovakian Section of the Budapest-Vienna Highway; available in Hungarian).

$\mathrm{NAH}$, fund "A Külügyminisztérium "adminisztratív« iratai, 1945-1994" ("Administrative" Documents of the Hungarian Ministry of Foreign Affairs, 1945-1994; hereinafter referred to only as XIX-J-1-k), carton 69, file "A Magyar-Csehszlovák Határrendező Bizottság jegyzőkönyvei 1947. október 11. és december 16. között" (The minutes of the HungarianCzechoslovakian Boundary Commission between 11 October and 16 December 1947; available in Hungarian).

$\mathrm{NAH}$, fund "A Külügyminisztérium »titkos" iratai, 1945-1995" ("Secret" Documents of the Hungarian Ministry of Foreign Affairs, 1945-1995; hereinafter referred to only as XIX-J-1-j), carton 48, file "Magyar-Csehszlovák Határrendező Bizottság" (HungarianCzechoslovakian Boundary Commission; available in Hungarian).

NAH, XIX-J-1-k, carton 48, file "Vegyes" (Miscellaneous), doc. "Zászló-gyalázás" (Desecrated Flag, 12 May 1948; available in Hungarian).

39 NAH, XIX-J-1-k, carton 70, doc. No. 1136/Pol. 1948, "Elöterjesztés Állami Határügyi Bizottság szervezésére" (Proposal for the Organization of the State Commission for Border Affairs, 18 March 1948; available in Hungarian). 
NAH, XIX-J-1-k, carton 70, doc. No. 1136/Pol. 1948, "Előterjesztés Állami Határügyi Bizottság szervezésére" (Proposal for the Organization of the State Commission for Border Affairs, 18 March 1948; available in Hungarian).

$\mathrm{NAH}, \mathrm{XIX}-\mathrm{J}-1-\mathrm{k}$, carton 70, doc. No. 22.323, "Kormánybizottsági jelentés az 1948. október 9-én aláirt l. számú Pótjegyzőkönyv francia szövegének megállapítása tárgyában Prágában folytatott tárgyalásokról" (Government Commission Report on the Prague Negotiations Relating to the Determination of the French Text of the Supplementary Protocol No. 1 signed on 9 October 1948; available in Hungarian).

$\mathrm{NAH}, \mathrm{XIX}-\mathrm{J}-1-\mathrm{k}$, carton 70, doc. "Kormánybizottsági jelentés a Magyar Köztársaság és a Csehszlovák Köztársaság között a párisi békeszerződés 1. cikk 4. pont »cu alpontja értelmében foganatosított területátengedéssel kapcsolatos vízügyi kérdések tárgyában Bratislavában 1948. évi október hó 9. napján aláírt egyezmény francia szövegének megállapítása iránt Prágában folytatott tárgyalásokról" (Government Commission Report on the Prague Negotiations relating to the Determination of the French Text of the Agreement between the Hungarian Republic and the Czechoslovakian Republic in Bratislava signed on 9 October 1948, on Water Issues that Arose from the Territorial Ceding Under Sub-point "c" of Point 4 of Article 1 of the Paris Peace Treaty. 1 March 1949; available in Hungarian).

NAH, XIX-J-1-k, carton 70, doc. "Zárójegyzőkönyv a párisi békeszerződés 1. cikke 4. pontjának "d« alpontja értelmében a magyar és a csehszlovák kormány képviselöiből alakított Határrendező Bizottság munkálatairól" (Final Protocol on the Work of the Boundary Commission Composed of the Representatives of the Hungarian and the Czechoslovakian Governments through Article I., 4. /d/ of the Paris Peace Treaty; available in Hungarian).

NAH, XIX-J-1-k, carton 70, file "Határrendező Bizottság jegyzőkönyvei" (Minutes of the Boundary Commission), doc. "I. számú pótjegyzökönyv a Bratislavában 1947. évi december 22.-én kelt Zárójegyző́önyvhöz a határkitúzési munkálatok tárgyában" (Supplementary Protocol No. 1 on the Works of Determining the Location of the Border to the Final Protocol in Bratislava dated on 22 December 1947; available in Hungarian).

$\mathrm{NAH}$, XIX-J-1-k, carton 70, file "Határrendező Bizottság jegyzőkönyvei" (Minutes of the Boundary Commission), doc. "II. Pótjegyzökönyv a párisi békeszerződés 1. cikk 4. pontjának »d« alpontja értelmében a magyar és csehszlovák kormány képviselóiböl alakított Határrendező Bizottság munkálatairól szóló, Bratislavában 1947. évi december hó 22-én kelt Zárójegyzökönyvhöz" (Supplementary Protocol No. 2 to the Final Protocol on the Works of the Boundary Commission, which was Composed of the Representatives of the Hungarian and Czechoslovakian Governments According to the Sub-point »d« of Point 4 of Article 1 of the Paris Peace Treaty, in Bratislava dated on 22 December 1947; available in Hungarian).

NAH, XIX-J-1-k, carton 71, doc. "Jelentés a záró ülésszakról" (Report on the Final Term; available in Hungarian).

NAH, XIX-J-1-k, carton 71, doc. "Kormánybizottsági elnöki jelentés a Magyar-Csehszlovák Határrendező Bizottság tárgyalásainak újrafelvételéröl" (Report of the Chairman of the Government Commission on the Resumption of the Negotiations of the HungarianCzechoslovakian Boundary Commission, 23 August 1948; available in Hungarian). 
NAH, XIX-J-1-k, carton 71, doc. "Kormánybizottsági jelentés a Magyar-Csehszlovák Határrendező Bizottság 1948. évi második ülésszakáról" (Government Commission Report on the Second Term of the Hungarian-Czechoslovakian Boundary Commission, 15 August 1948; available in Hungarian).

$\mathrm{NAH}$, XIX-J-1-k, carton 71, file "Külügybe jelentések" (Reports to the Ministry of Foreign Affairs), doc. "Vázlatos tájékoztató jelentés a Magyar Határrendező Bizottság tárgyalásainak állásáról 1948. július 8-án" (Schematic Information Report on the Progress of the Negotiations of the Hungarian Boundary Commission on 8 July 1948. By Roland Kiss; available in Hungarian).

NAH, XIX-J-1-k, carton 71, file "Pesti előkészítő iratok" (Pest Preparatory Papers), doc. "Jelentés Miniszter Úrnak a határrendezó bizottság tagjairól" (Report to the Minister on the Members of the Boundary Commission. Budapest, 3 October 1947; available in Hungarian).

NAH, XIX-J-1-k, carton 71, file "Víz" (Water), doc. "Egyezmény a Magyar Köztársaság és a Csehszlovák Köztársaság között a párisi békeszerződés 1. cikk 4. pontjának "C« bekezdése értelmében foganatosított területátengedéssel kapcsolatban felmerülő egyes vízügyi kérdések tárgyában" (Agreement between the Hungarian Republic and the Czechoslovakian Republic on Individual Water Issues that Arose from the Territorial Ceding Under Paragraph »c« of Point 4 of Article 1 of the Paris Peace Treaty; available in Hungarian).

NAH, XIX-J-1-k, carton 71, file "Víz" (Water), doc. "Jegyzőkönyv a magyar-csehszlovák Határrendező Bizottság Vízügyi Albizottságának Bratislavában, 1948. évi január hó 9-től január hó 15-ig tartott tárgyalásairól" (Protocol on the Negotiations of the Water SubCommission of the Hungarian-Czechoslovakian Boundary Commission in Bratislava from 9 to 15 January 1948; available in Hungarian).

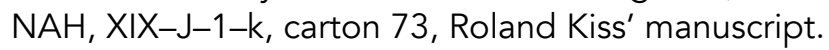

HOLLÓSI, Gábor: Az "emberi és polgári jogok" értelmezése pozsonyi hídfő kiszélesítése kapcsán [The meaning of "human and civic rights" in connection with the enlargement of the Bratislava bridgehead], in: lustum Aequum Salutare, 12, 2016, 3, 143.

HOLLÓSI, Gábor: A pozsonyi hídfö. A Magyar-Csehszlovák Határrendező Bizottság tárgyalásai (1947-1949) [The Bratislava Bridgehead: The Negotiations of the HungarianCzechoslovakian Boundary Commission (1947-1949)], Budapest 2017.

HORVÁTH, Attila: A Beneš-dekrétumok és a hozzá kapcsolódó magyarellenes intézkedések (1945-1949) [The Beneš decrees and the anti-Hungarian measures connected to them (1945-1949)], in: Kisebbségvédelem. A Kisebbségi Jogvédő Intézet Tudományos Folyóirata [Protection of Minorities. The Academic Journal of the Institute for the Protection of Minority Rights (IPMR)], 1, 2019, 1, 144-158.

JAKABFFY, Imre: A pozsonyi hídfő [The Bratislava Bridgehead], in: Életünk [Our Life], 36, 1998, 10, 891-919.

ROMSICS, Ignác: Az 1947-es párizsi békeszerződés [The 1947 Paris Peace Treaty], Budapest 2006.

The Universal Declaration of Human Rights, online: www.un.org.

Treaty of Peace with Hungary - 10 February 1947, online: https://www.loc.gov/law/help/ us-treaties/bevans/m-ust000004-0453.pdf. 


\section{Author}

Dr. Gábor Hollósi, PhD.

VERITAS Történetkutató Intézet és Levéltár VERITAS Research Institute and Archives

Zsil utca 2-4, 1093 Budapest, Hungary gabor.hollosi@veritas.gov.hu 